\title{
THE EXPERMENTAL CORRELATON BETWEEN HEAT TREATMENT PARAMETER AND CORROSION BEHAVIOUR OF 718 SERIES Ni-Fe SUPERALLOY in $\mathrm{H}_{2} \mathrm{SO}_{4}$ SOLUTION
}

\author{
${ }^{1}$ Nwogbu C. C; ${ }^{2}$ Nwogbu Paul I. ${ }^{3}$ Agbo Alfred \\ ${ }^{1 \& 3}$ Depatment of Metallurgical and Materials Engineering, \\ Enugu State University of Science and Technology, Enugu, Nigeria. \\ ${ }^{2}$ Department of Chemical Engineering, \\ Enugu State University of Science and Technology, Enugu, Nigeria.
}

\begin{abstract}
The correlation between heat treatment parameter and corrosion behavior of $718 \mathrm{Ni}-\mathrm{Fe}$ superalloy was investigated in $\mathrm{H}_{2} \mathrm{SO}_{4}$ solution. Spark plasma sintering (SPS) was used in producingthe samples which was then heat treated at temperatures of $800^{\circ} \mathrm{C}$ and $1000^{\circ} \mathrm{C}$ and time of 1 and 2 hours for each temperature. Electrochemical studieswere carried out in $\mathrm{H}_{2} \mathrm{SO}_{4}$ medium, using potentiodynammic anodic polarization techniques. It was observed from the results that the heat-treated alloy showed better corrosion resistance than the untreated alloy. Heat treatment temperature and time have great influences on the corrosion behavior and morphology of the alloy. An optimal protection efficiency of $55.29 \%$ was given by sample heat treated at $800^{\circ} \mathrm{C}$ for 2 hours.it has been established that heat treatment can be used to improve the corrosion resistance of the alloy.
\end{abstract}

Keywords: Ni-Fe alloy, Microstructure, Corrosion and Heat Treatment

\subsection{INTRODUCTION}

Nickel-Iron base alloys appear to be a promising alternative to austenitic stainless steels because of their better corrosion resistance, thermal conductivity and mechanical properties. Using these alloys, complex processes and waste streams can be handled safely due to their high corrosion resistance. [1,2]. Theses alloys possess higher tolerance for alloying elements in solid solution than stainless steels and other iron base alloys [3]. The good metallurgical stability of the nickel base alloys makes them a better alternative to stainless steel $[4,5]$. Owing to the excellent mechanical and physical properties, nickel base superalloys are extensively employed in nuclear power plants [6].

INCONEL 718 alloy can be fabricated with ease, combined with it good tensile, fatigue, creep, and rupture strength, have resulted in its use in a wide range of applications. Ithas been widely used in the aircraft industry due to its high-strength, corrosion-resistantand excellent mechanical properties at elevated temperatures [7-9]. INCONEL718 is strengthened mainly by the nano-scale $\gamma^{\prime \prime}\left(\mathrm{Ni}_{3} \mathrm{Nb}\right)$ and $\gamma^{\prime}\left(\mathrm{Ni}_{3}(\mathrm{Al}, \mathrm{Ti})\right.$ phases. The $\gamma^{\prime \prime}$ phase has a disc shape with a body centered tetragonal (bct) structure $[10,11]$. The $\gamma^{\prime}$ 'phase has a cubic (fcc) structure and precipitates as a cube-to-cube relationship with the matrix [12]. There will be more $\gamma$ " than $\gamma$ ' in the alloy due to it composition. The $\gamma$ " phase is metastable and can transform into the $\delta$ $(\mathrm{Ni3Nb})$ phase at high temperatures [13-15]. Adequate amounts of $\delta$ phases at grain boundaries can refine the grain sizes and improve the resistance to grain boundary creep fracture [16-18) 
The high temperature performance of the Ni-base superalloy Superni-75 has been evaluated under cyclic conditionsfor 1000hinreal service environment of the waste incinerator based upon medical waste as fuel. The performance has been characterized via surface morphology, phase composition and element concentration using the combined techniques of XRD, SEM/EDX, BSEI and EPMA. Initially, due to chlorine-based corrosion attack on the Superni-75 alloy, there was inner penetration of the corrosive species. However, with the growth of a thin $\mathrm{Cr}_{2} \mathrm{O}_{3}$ interface layer along the scale/surface boundary, the performance of the alloy improved against the attack by the flue gases in the real service conditions of the medical waste incinerator. Boiler tubes made of Superni-75 were estimated to have an erosion-corrosion rate of about 65 mils/year.

Paula Rojas [19] reported on the electrochemical behavior and corrosion resistance of glassy Fe68.6-Ni28.2-Mn3.2 (at\%) specimens which were studied in different concentrations of acid solutions. The results indicated that the corrosion rate increased with increasing concentration of the acid solutions. Electrochemical impedance spectroscopy results were analyzed by fitting the experimental data to an equivalent circuit using the ZSim Demo program, and suitable equivalent circuit models were determined. The results obtained from the impedance and polarization measurements are in good agreement. The thermodynamic parameters were evaluated for the corrosion process and discussed. In order to further research in this novel area for better service condition, the present work has been undertaken.

\subsection{MATERIALS AND METHOD}

A spark plasma sintering machine (model SPS 10-3), manufactured by Thermal Technologies LLC, was used to produce the alloy samples. Specimens of diameter $100 \mathrm{~mm}$ were produced using dies and punches of graphite. The samples were produced at a temperature of $1150^{\circ} \mathrm{C}$ temperature and a pressure of $5 \mathrm{MPa}$ with heating and cooling rate of $10^{\circ} \mathrm{C} / \mathrm{Min}$. the thermocouple inserted into the bottom punch was used to measure the temperature. All the samples were produced in a closed furnace where 10-2 torr vacuum was maintained throughout the experiment. A standard Ni-Fe base superalloy (INCONEL718) with composition shown in Table 1 below was used.

Table 1: Composition of the superalloy INCONEL 718 used (wt\%)

$\begin{array}{cccccccccc}\mathrm{Ni} & \mathrm{Fe} & \mathrm{Cr} & \mathrm{Mo} & \mathrm{Mn} & \mathrm{Si} & \mathrm{C} & \mathrm{Al} & \mathrm{Ti} & \text { Other } \\ 53 & 18.5 & 18.6 & 3.1 & 0.3 & 0.4 & 0.4 & 0.4 & 0.9 & 5.0 \mathrm{Co}\end{array}$

A carbolite furnace was used for the heat treatment of the samples. The samples were placed inside the furnace and the following heat treatment programme was used.

i. Hold at $100^{\circ} \mathrm{C}$ for 1 and 2 hours: then rapidly cool by quenching in water.

ii. Hold at $800^{\circ} \mathrm{C}$ for 1 and 2 hours; then air cool,

$\mathrm{X}$-ray diffraction (XRD) analysis, with $\mathrm{Cu}-\mathrm{K} \alpha$ radiation, was conducted using a PANalyticalX'Pert PRO. The XRD was operated at 45KV voltage and 40mA current.

The $2 \theta$ angles between $1^{0}$ and $90^{\circ}$ were scanned and analyzed using the Bragg Law. A Rietveld refinement software, TOPAS ${ }^{\mathrm{TM}}$ was used for quantitative analysis. A TESCAN Scanning Electron Microscope was used in the research. The polished and etched samples were firmly held in the sample holder using a double-sided carbon tape before putting them inside the sample chamber. The SEM was operated at an accelerating voltage of $20 \mathrm{KV}$.

Electrochemical measurements were carried out using an Autolabpotentiostat with the General purpose Electrochemical Software package. The samples were cold mounted with epoxy leaving a working surface was ground with grinding papers from 600 to 1000 grit, and 
then cleaned with the distilled water and ethanol. A conventional three electrode cell, consisting of $\mathrm{Ag} / \mathrm{AgCl}$, Platinum and samples was used as: reference, counter and working electrodes respectively. The medium used for the electrochemical measurement was $0.5 \mathrm{MH}_{2} \mathrm{SO}_{4}$. The measurement was carried out at room temperature. The potentiodynamic potential scan was fixed from $-1.5 \mathrm{~V}$ to $+1.5 \mathrm{~V}$ with a scan rate of $0.012 \mathrm{~V} / \mathrm{s}$.

\subsection{RESULTS AND DISCUSSION}

Figure 1a shows the XRD pattern of the untreated alloy, while Figures 1b-1e display the XRD patterns of the heat treated samples. From the XRD spectrum of the alloy, it is observed clearly that there is presence of $\mathrm{Ni}, \mathrm{Fe}$ (Awaruite), $\mathrm{AL}_{0.3} \mathrm{Fe}_{3} \mathrm{Si}_{0.7}$ (Aluminum iron Silicon), and $\mathrm{Cr}_{7} \mathrm{C}_{3}$ (carbon Chromium) phases. After heat treatment it is observed that new phases appeared such as: FeSi (Fersilicite, syn [NR]), Managnese Carbide, Chromium Iron Carbide, Managanese Silicon Carbide. The presence of ( $\mathrm{Ni}, \mathrm{Fe})$ (Awaruite) phase is common to all the samples; this expected because the specimen is a Ni-Fe base superalloy. By comparing the XRD of the control (Figure 1a) with the heat treated samples (Figures 1b-1e), one can observe that there is a great change in the spectrum which resulted in more diffraction peaks, and a larger quantity of hard carbides with smaller inter-particle distance. In the heat treated samples, it is clear that the various phases formed after the heat treatment depends on the heat treatment condition as shown in Table 2.

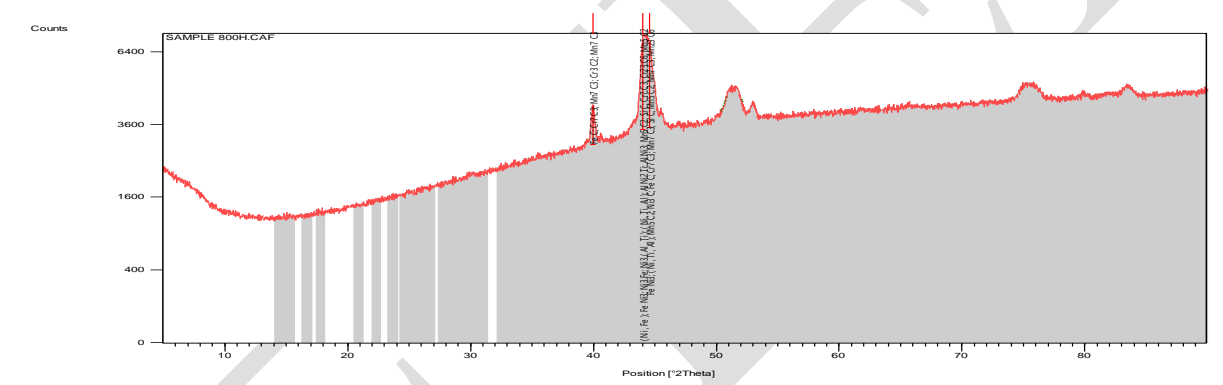

Figure 1a: XRD spectrum of the untreated alloy

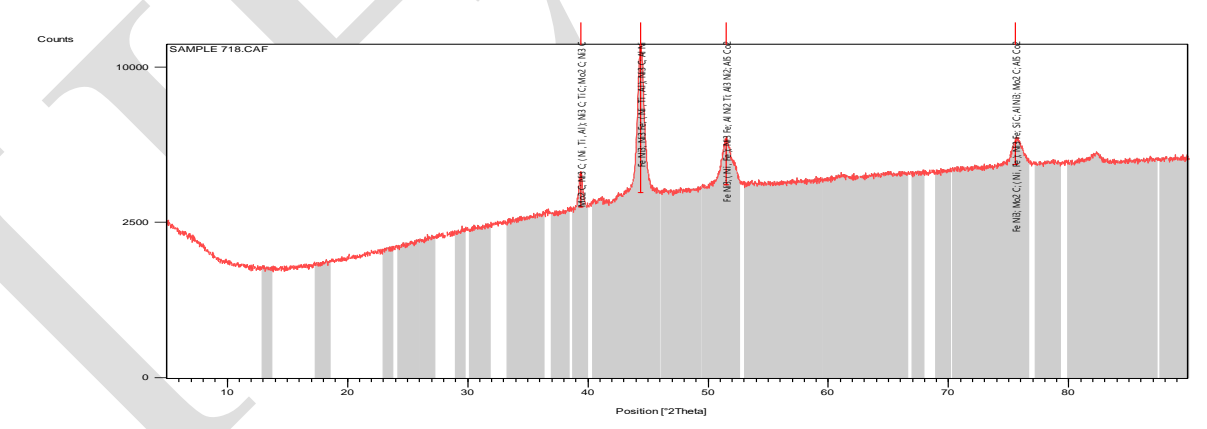

Figure 1b: XRD spectrum of alloy heat treated at HT10001hr

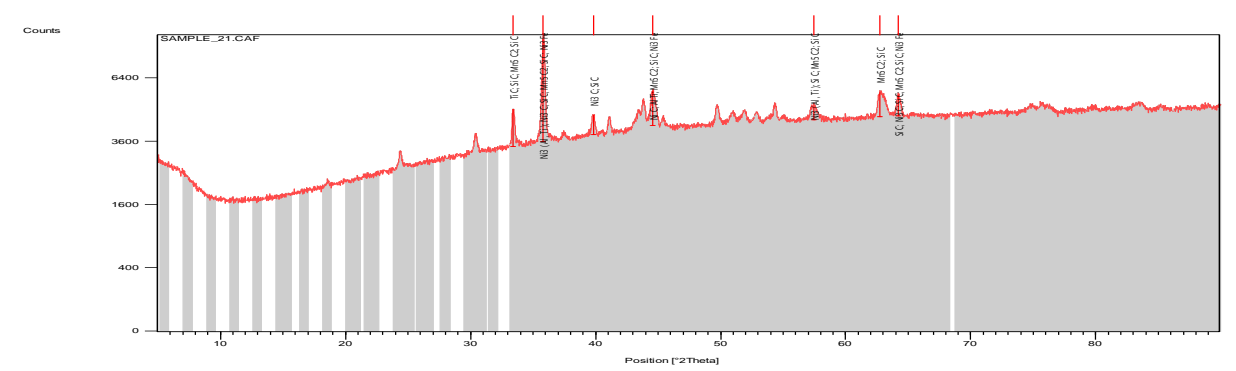

Figure 1c: XRD spectrum of alloy heat treated at HT10002hrs 


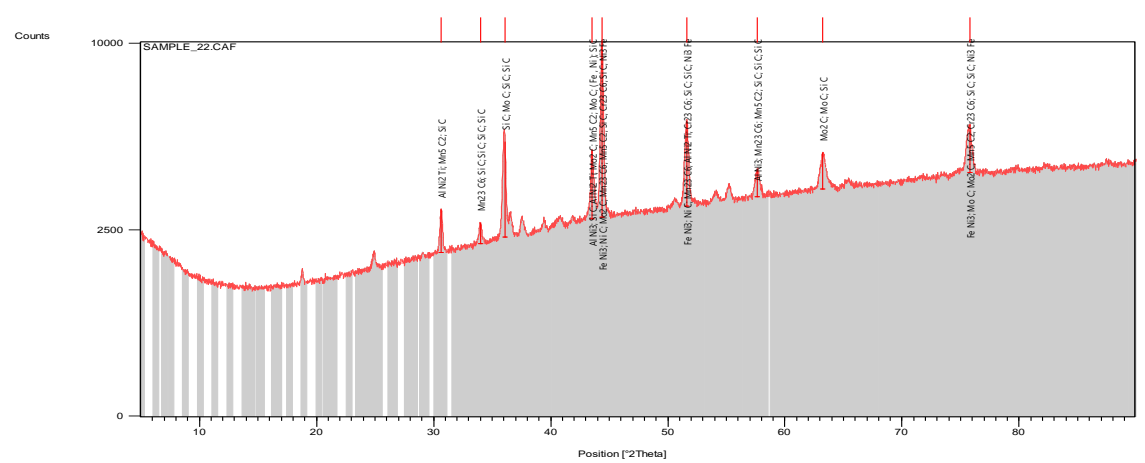

Figure 1d: XRD spectrum of alloy heat treated at HT8001hr

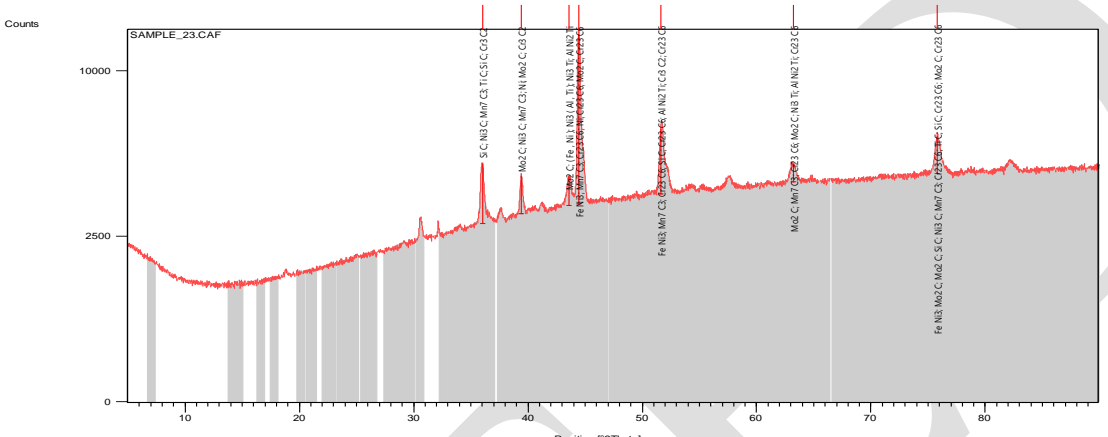

Figure 1e: XRD spectrum of alloy heat treated at HT8002hrs

Table 2: Identified patterns list

\begin{tabular}{|c|c|c|c|c|}
\hline Control & HT10001HR & HT10002HR & HT8001HR & HT8002HR \\
\hline $\begin{array}{ll}(\mathrm{Ni}, & \mathrm{Fe}) \\
\text { (Awaruite) } & \\
\end{array}$ & $\begin{array}{l}\text { (Ni,Fe) } \\
\text { (Awaruite) }\end{array}$ & $\begin{array}{l}\mathrm{Ni}, \mathrm{Fe}) \\
\text { Awaruite) }\end{array}$ & $\begin{array}{l}\mathrm{Ni}, \mathrm{Fe}) \\
\text { Awaruite) }\end{array}$ & $\mathrm{Al} \mathrm{Cr} \mathrm{Fe} 2$ \\
\hline $\begin{array}{l}\text { Al0.3 Fe3 Si0.7 } \\
\text { (Aluminum Iron } \\
\text { Silicon) }\end{array}$ & $\begin{array}{l}\text { Mn5 c2 } \\
\text { (Manganese } \\
\text { Carbide) }\end{array}$ & $\begin{array}{l}\mathrm{Al} \mathrm{Ni2} \quad \mathrm{Ti} \\
\text { (Aluminum } \\
\text { Nickel Titanium }\end{array}$ & $\begin{array}{l}\text { Fe Si(Fersilicite, } \\
\text { syn }[N R])\end{array}$ & $\begin{array}{l}\mathrm{Fe} \\
\mathrm{Si}(\text { Fersilicitie, } \\
\text { syn }[\mathrm{Nr}])\end{array}$ \\
\hline $\begin{array}{l}\text { Cr7C3 (Carbon } \\
\text { Chromium) }\end{array}$ & $\begin{array}{l}\text { Al0.5 } \mathrm{Fe} 0.5 \\
\text { (Aluminum } \\
\text { Iron) }\end{array}$ & $\begin{array}{l}\text { Al0.96 Ni1.04 } \\
\text { (Aluminum } \\
\text { Nickel) }\end{array}$ & $\begin{array}{l}\mathrm{C} 0.12 \quad \mathrm{Fe} 0.79 \\
\mathrm{Si0} .09 \quad \text { (Carbon } \\
\text { Iron Silicon) }\end{array}$ & $\begin{array}{ll}\mathrm{Fe} & \mathrm{Ni3} \\
\text { (Awaruite) }\end{array}$ \\
\hline $\begin{array}{l}\text { Ni3 (Al, Ti) } \\
\text { (Udimet 500') }\end{array}$ & $\begin{array}{ll}\mathrm{Mn} & \mathrm{Si} \\
\text { (Manganese } & \\
\text { Silicon) } & \\
\end{array}$ & $\begin{array}{ll}\text { Fe7 C3 } & \text { (Iron } \\
\text { Cabide) } & \end{array}$ & $\begin{array}{ll}\mathrm{Fe} 3 & \mathrm{C} \\
\text { (Cementite) }\end{array}$ & $\begin{array}{l}\text { Ni2 Si (Nickel } \\
\text { Silicon) }\end{array}$ \\
\hline & $\begin{array}{l}(\mathrm{Cr}, \mathrm{Fe}) 7 \text { C3 } \\
\text { Chromium iron } \\
\text { Carbide })\end{array}$ & $\begin{array}{l}\text { Al0.4 } \mathrm{Fe} 0.6 \\
\text { (Aluminum } \\
\text { Iron) }\end{array}$ & $\begin{array}{ll}\text { Cr3 } & \mathrm{Ni} 2 \\
\text { (Chromium } & \\
\text { Nickel) } & \\
\end{array}$ & $\begin{array}{l}\text { Mn 15C4 } \\
\text { (Manganese } \\
\text { Carbide) }\end{array}$ \\
\hline & $\begin{array}{ll}\text { Ni2.67 Ti1.33 } \\
\text { (Nickel } \\
\text { Titanium) } \\
\end{array}$ & $\begin{array}{ll}\text { Cr22 } & \text { C6 } \\
\text { (Carbon } & \\
\text { Chromium) } & \\
\end{array}$ & $\begin{array}{l}\mathrm{Al} 2 \\
\text { (Aluminum } \\
\text { Titanium) }\end{array}$ & $\begin{array}{l}(\mathrm{Cr}, \mathrm{Fe}) 7 \quad \mathrm{C} 3 \\
\text { (Chromium Iron } \\
\text { Carbide) }\end{array}$ \\
\hline & $\begin{array}{l}\text { Mn22.6 Si5.4 } \\
\text { C4 (Manganese } \\
\text { Silicon Carbide) }\end{array}$ & & $\begin{array}{l}\text { Ni74 Si26 } \\
\text { (Nickel Silicon) }\end{array}$ & \\
\hline
\end{tabular}


From the Figures 2a-2e, one can observe a great difference between the morphology of the untreated alloy (see figure 2a) and those of the heat treated samples (see figures $2 \mathrm{~b}-2 \mathrm{e}$ ). Samples heat treated for $1 \mathrm{hr}$ have a more refined structure. The dark spots show the presence of some of the new phases developed during heat treatment.

The electrochemical potential of the alloy was investigated using $\mathrm{H}_{2} \mathrm{SO}_{4}$ solution. Table 3 presents the corrosion data including the corrosion rate, while Fig 3(a) and 3 (b) present results of the polarization tests. From the results obtained in Table 3 and Figure 3, the corrosion rate of the sample generally decreases after heat treatment. The untreated sample has the higher corrosion rate. This was attributed to the high anodic potential reached by the sample. Meanwhile, as the sample was heat treated there was decrease in corrosion rate. This may be attributed to the formation of a hard thin film, which may have retarded the ingress of $\mathrm{SO}_{4}^{-2}$ ions. As the heat treatment time decrease from 2 to $1 \mathrm{hr}$ the corrosion rate of the alloy decreased. Heat treatment contributes immensely to the corrosion behavior of the alloy (see Figure 3) E.g Corrosion rates of 2.55( untreated), 1.302, 3.59, 1.835 and $1.14 \mathrm{~mm} /$ year were obtained for samples heat treated at $1000^{\circ} \mathrm{C}$ for $1,2 \mathrm{hrs}$ and $800^{\circ} \mathrm{C}$ for $1,2 \mathrm{hrs}$ respectively. The various hard phases formed after heat treatments are the major factor responsible for the improvement in the corrosion behavior of this alloy.

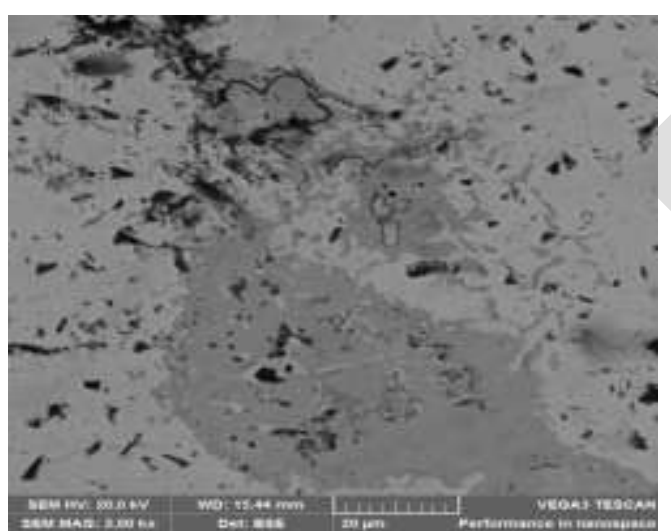

Figure 2a: SEM image of untreated alloy

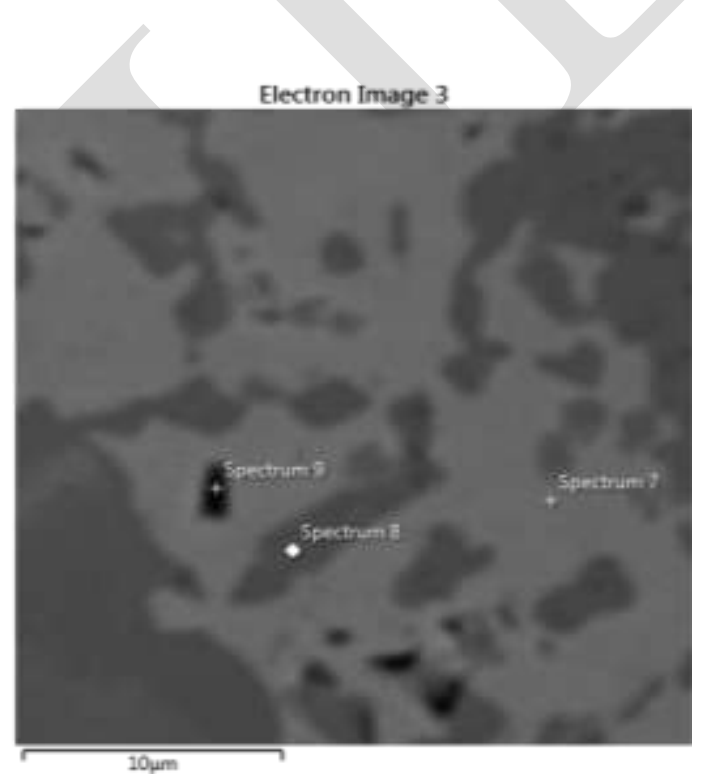

Figure 1b: SEM image of alloy heat treated at HT10001hr

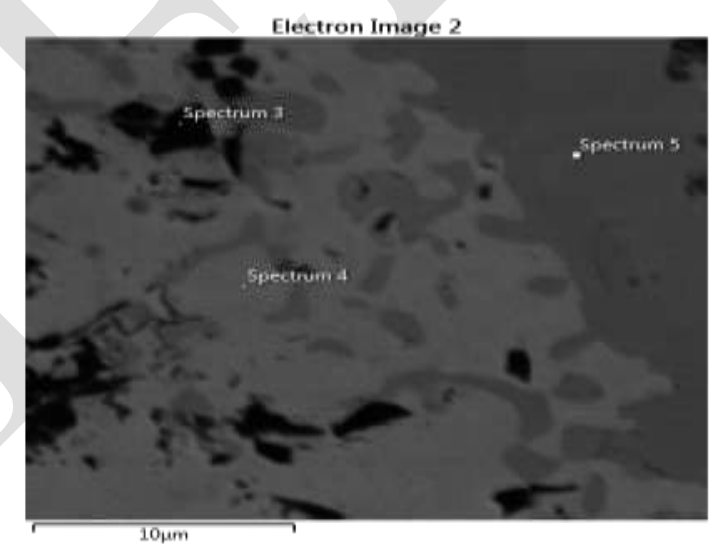

Figure 2c: SEM image of alloy heat treated at HT10002hrs

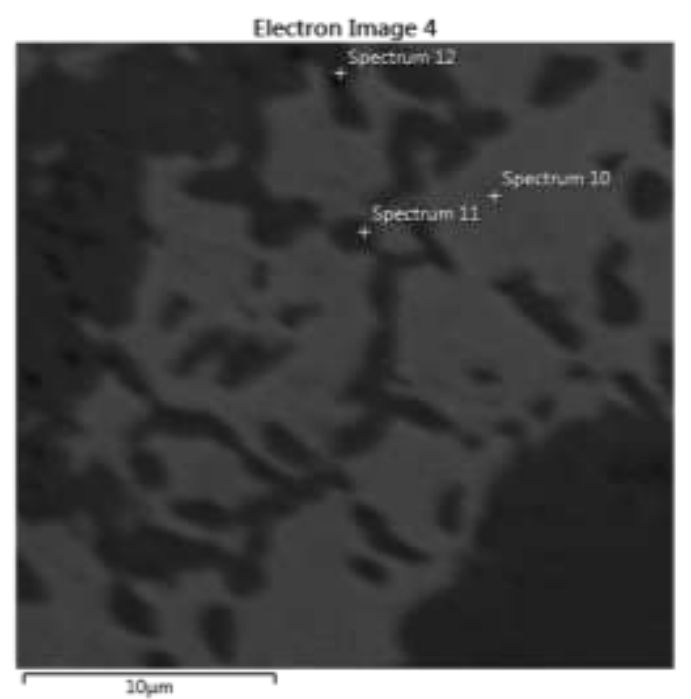

Figure 2d: SEM image of alloy heat treated at HT8001hr 


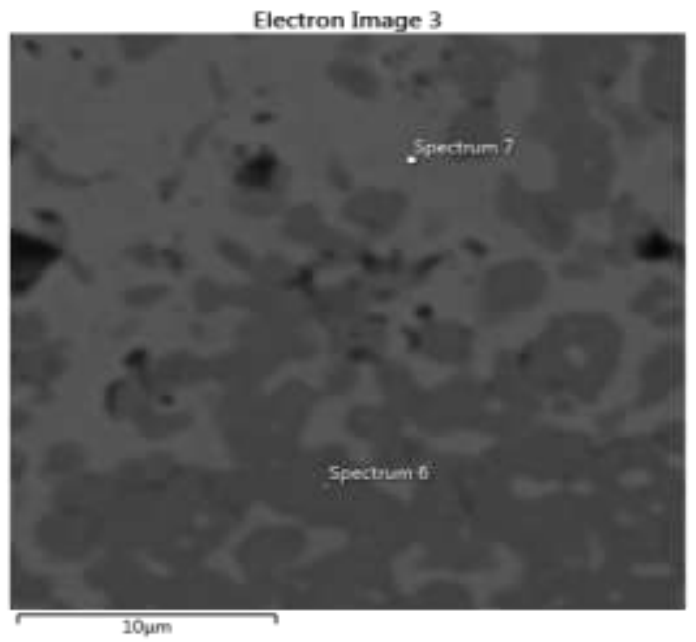

Figure 2e: SEM image of alloy heat treated at HT8002hrs

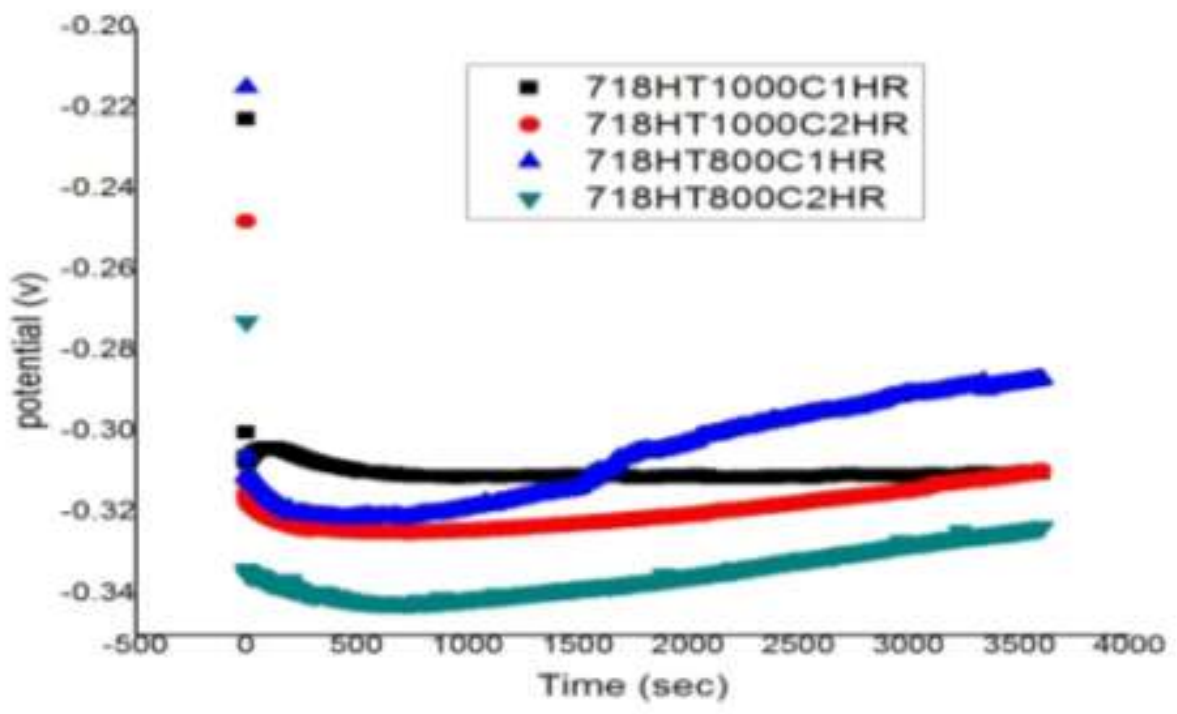

Figure 3a: Variation of open circuit potential with time

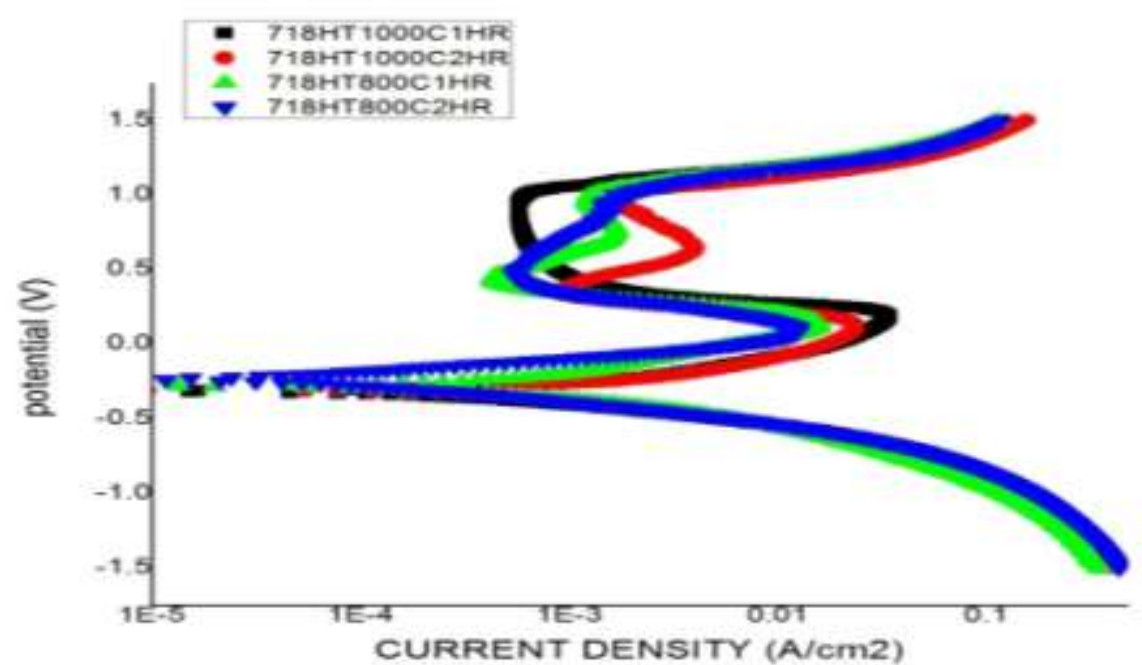

Figure 3b: potentiodynamic polarization curve 
Table 3a: Electrochemical corrosion data

\begin{tabular}{|c|c|c|c|c|c|c|}
\hline SAMPLE & $\mathbf{E}_{\text {corr }}$ & $\mathbf{I}_{\text {corr }}(\mathbf{A} / \mathbf{c m} 2)$ & $\mathbf{R}_{\mathbf{p}}(\mathbf{\Omega})$ & $\boldsymbol{\beta}_{\mathbf{a}}(\mathbf{V} / \mathbf{d e c}$ & $\boldsymbol{\beta}_{\mathbf{c}}(\mathbf{V} / \mathbf{d e c})$ & $\mathbf{C R}(\mathbf{m m} / \mathbf{Y})$ \\
\hline Control & -0.359 & $2.35 \mathrm{E}-04$ & $1.69 \mathrm{E}+01$ & 0.064 & 0.112 & $2.55 \mathrm{E}+00$ \\
\hline 718HT1000C1HR & -0.316 & $1.199 \mathrm{E}-4$ & $2.264 \mathrm{E}+1$ & 0.059 & 0.083 & $1.302 \mathrm{E}+0$ \\
\hline 718HT1000C2HRS & -0.309 & $3.31 \mathrm{E}-04$ & $1.71 \mathrm{E}+01$ & 0.08 & 0.128 & $3.59 \mathrm{E}+00$ \\
\hline 718HT800C1HR & -0.366 & $1.708 \mathrm{E}-4$ & $1.62 \mathrm{E}+1$ & 0.054 & 0.093 & $1.853 \mathrm{E}+0$ \\
\hline 718HT800C2HRS & 0.279 & $1.05 \mathrm{E}-04$ & $7.25 \mathrm{E}+01$ & 0.113 & 0.122 & $1.14 \mathrm{E}+00$ \\
\hline
\end{tabular}

Table 3b: Upper and lower levels used with their

\begin{tabular}{|l|l|l|l|}
\hline S/No & Temperatures (A) 0C & Time (B) hrs & $\begin{array}{l}\text { Corrosion rate } \\
(\mathrm{mm} / \mathrm{yr})\end{array}$ \\
\hline 1 & 800 & 1 & $1.853 \mathrm{E}+0$ \\
\hline 2 & 1000 & 2 & $3.59 \mathrm{E}+00$ \\
\hline 3 & 1000 & 1 & $1.302 \mathrm{E}+0$ \\
\hline 4 & 800 & 2 & $1.14 \mathrm{E}+00$ \\
\hline
\end{tabular}

The heat treated sample may act as a cathode, which prevents conductance of ions but allows electronic conductance to some extent. It should also be emphasized that the electrical potential in all the samples decreases in the direction from the anode to the cathode (positive ions move towards the cathode, negative ions towards the anode (see Figures 3a). The surface of the anode in reality is much smaller than that of the cathode;i.e. the electrolytic current density is much higher near the anode. It is worthy to note in this present work that heat treatment temperature and time play a vital role in the electrochemical potential of all the samples. The optimum condition that led to the higher corrosion resistance is the sample heat treated at HT8002hrs. This optimum condition gave a protection efficiency of 55.29\%.

Two factors and level of factorial design experiment were used to study the influences of heat treatment temperature and time on the corrosion behaviour of the materials. Table $3 \mathrm{~b}$, shows the upper and lower level s of each variable with their response values..Figure 4, shows the estimated response surface for the samples. It is observed that the corrosion rate increases with increase in heat treatment temperature and time.Forexample as the temperature increases from 800 to $1000^{\circ} \mathrm{C}$ and the time from 1 to 2 hours the corrosion rate increased rapidly (see figure 4). Equation 1 shows the dependence of corrosion rate on temperature and time.

Corrosion rate $=1.97125+0.47475^{*}$ Temperature $+0.39375^{*}$ Time

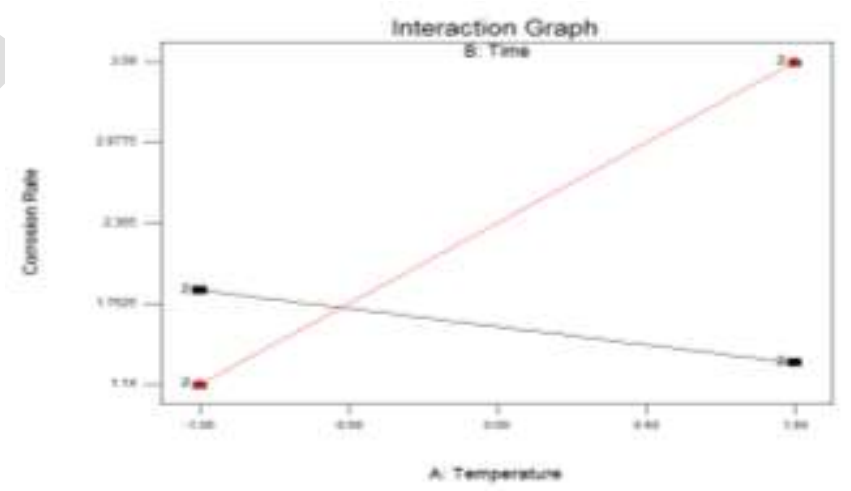

Figure 4a: Interaction curve for the corrosion behavior 


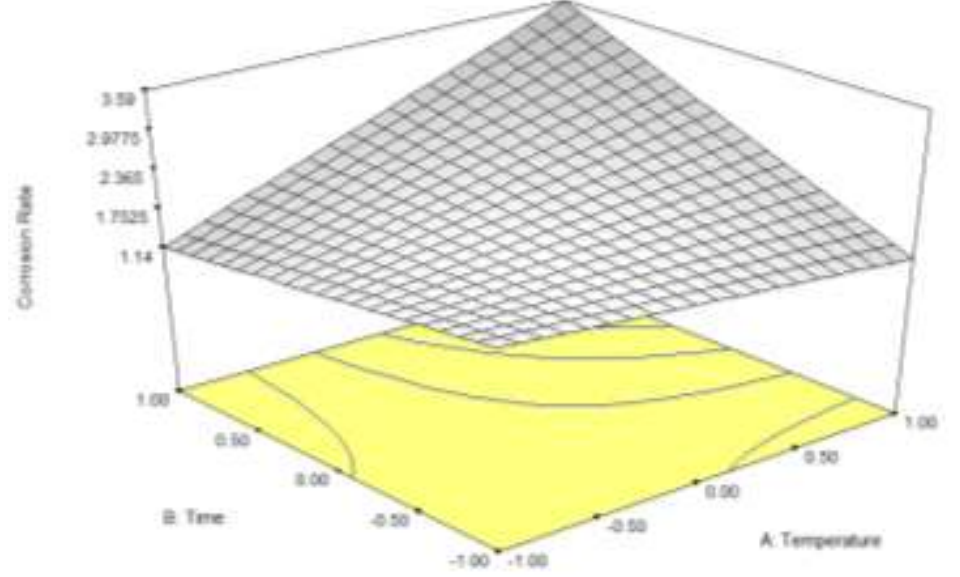

Figure 4b: 3-D plot for the corrosion behavior of the 718 alloy

From equation 1, it can be clearly seen that the coefficients associated with temperature and time are positive. It indicates that as the temperature rises from 800 to $1000^{\circ} \mathrm{C}$, the corrosion rate rises by 0.47475 . Also as the time increases from 1 to 2 hours the corrosion rate rises by 0.39375.This further supports the earlier observation in figure $4 \mathrm{a}$ and $4 \mathrm{~b}$ analysis of variance (ANOVA) was used to determine the design parameters significantly influencing the corrosion rate. Table $3 \mathrm{~b}$ shows the results of ANOVA at $95 \%$ confidence level (significant level of $\propto=0.05$ ). The last column of table $3 \mathrm{c}$ shows the contribution ( $\mathrm{p}$ ) of each parameter to the response, indicating the degree of influence on the results.

The "Model F-value" of 0.34 implies the model is not significant relative to the noise. There is a $77.25 \%$ chance that a "Model F-value" this large could occur due to noise. Values of "prob > F"' less than 0.0500 indicate that the model terms are significant. In this case, A (Temperature) and B (time) are not significant model terms

Table 3c: ANOVA for selected factorial model

\begin{tabular}{|l|l|l|l|l|l|}
\hline Source & $\begin{array}{l}\text { Sum of } \\
\text { squares }\end{array}$ & DF & Mean square & F value & P value \\
\hline Model & 1.52 & 2 & 0.76 & 0.34 & 0.7725 \\
\hline A & 0.90 & 1 & 0.90 & 0.40 & 0.6408 \\
\hline B & 0.62 & 1 & 0.62 & 0.28 & 0.6923 \\
\hline Residual & 2.25 & 1 & 2.25 & & \\
\hline Cor Total & 3.77 & 3 & & & \\
\hline
\end{tabular}

\subsection{CONCLUSIONS}

From the results and discussion above the following conclusions can be made:

1. The heat treated alloy shows better corrosion resistance than the untreated alloy.

2. Heat treatment temperature and time have great influence on the corrosion behaviour and morphology of the alloy.

3. The sample heat treated at $800^{\circ} \mathrm{C}$ for 2 hours gave a highprotection efficiency of $55.29 \%$

4. It has been established that heat treatment can be used in improving the corrosion resistance of the alloy. 


\section{REFERENCES}

1. G.B. Viswanathan, P.M. Sarosi, M.F. Henry, D.D. Whitis, W.W. Milligan, M.J. Mills "Investgation of Creep Deformation Mechanisms at Intermediate Temperatures in Rene 88 DT." Acta Mater, 53, pp. 3041-3057, 2005.

2. D. Locq, A. Walder, M. Marty, P. Caron "Development of New PM Superalloys for High Temperature Application" EUROMAT, Intermetallics and Superalloys Vol. 10, WILEY-VCH Verlag Gmbh, Weinheim, Germany (D.G. Morris et al.,eds), pp. 52-57, 2000.

3. S.T. Wlodek, M. Kelly, D. Alden "The Structure of N18 Superalloys 1992" TMS, Warrendale, PA, U.S.A (S.D. Antolovichet al.,eds) ,pp. 467-476, 1992.

4. M. Soucail, M. Marty, H. Octor "Development of Coarse Gran Structures in a Powder Metallurgy Nickel Base Superalloy N18. Scripta Mater, 34, 4, pp.519-525, 1996.

5. Khadiah M. Emran, "Effects of concentration and temperature on the corrosion properties of the Fe-Ni-Mn alloy in HCL solutions." Res Chem Intermed (2015) 41: 3583-3596

6. W.A. Wesley and H.R. Copson, "Effect of Non-Condensable Gases on Corrosion of Nickel in Steam Condensate," TRANS. ELECTROCHEM. SOC.,May, 1949.

7. Li, L.; Gong, X.; Ye, X.; Teng, J.; Nie, Y.; Li, Y.; Lei, Q. Influence of Building Direction on the OxidationBehavior of Inconel 718 Alloy Fabricated by Additive Manufacture of Electron Beam Melting. Materials 2018,11, 2549.

8. Moussaoui, K.; Rubio, W.; Mousseigne, M.; Sultan, T.; Rezai, F. E_ects of Selective Laser Meltingadditive manufacturing parameters of Inconel 718 on porosity, microstructure and mechanical properties.Mater. Sci. Eng. A 2018, 735, 182-190.

9. Hua, Y.; Liu, Z. Experimental Investigation of Principal Residual Stress and Fatigue Performance for TurnedNickel-Based Superalloy Inconel 718. Materials 2018, 11, 879.

10. Calandri, M.; Manfredi, D.; Calignano, F.; Ambrosio, E.P.; Biamino, S.; Lupoi, R.; Ugues, D. SolutionTreatment Study of Inconel 718 Produced by SLM Additive Technique in View of the Oxidation Resistance. Adv. Eng. Mater. 2018, 20, 1800351.

11. Zhang, H.; Li, C.; Guo, Q.; Li, H.; Liu, Y. Deformation Mechanism of L12-0 Phase in Bimodal "-0Precipitation Hardened Inconel 718 Superalloy. Adv. Eng. Mater. 2018, 20, 1800652.

12. Ma, W.; Xie, Y.; Chen, C.; Fukanuma, H.; Wang, J.; Ren, Z.; Huang, R. Microstructural and mechanicalproperties of high-performance Inconel 718 alloy by cold spraying. J. Alloys Compd. 2019, 792, 456-467.

13. Lin, Y.C.; Yin, L.-X.; Luo, S.-C.; He, D.-G.; Peng, X.-B. E_ects of Initial_ Phase on Creep BehaviorsandFracture Characteristics of a Nickel-Based Superalloy. Adv. Eng. Mater. 2018, 20, 1700820.

14. Zhang, H.; Li, C.; Liu, Y.; Guo, Q.; Huang, Y.; Li, H.; Yu, J. E_ect of hot deformation on " and _ phaseprecipitation of Inconel 718 alloy during deformation\&isothermal treatment. J. Alloys Compd. 2017, 716, 65-72.

15. Sano, K.; Oono, N.; Ukai, S.; Hayashi, S.; Inoue, T.; Yamashita, S.; Yoshitake, T. "'$\mathrm{Ni3Nb}$ precipitate in Fe-Nibase alloy. J. Nucl. Mater. 2013, 442, 389-393.

16. Lyu, F.; Liu, F.; Hu, X.; Yang, X.; Huang, C.; Shi, D. The delta Phase Precipitation of an Inconel 718 SuperalloyFabricated by Electromagnetic Stirring Assisted Laser Solid Forming. Materials 2019, 12, 2604.

17. Nunes, R.M.; Pereira, D.; Clarke, T.; Hirsch, T.K. Delta Phase Characterization in Inconel 718 Alloys ThroughX-ray Di_raction. ISIJ Int. 2015, 55, 2450-2454. 
18. Deng, D.; Moverare, J.; Peng, R.L.; Söderberg, H. Microstructure and anisotropic mechanical properties ofEBM manufactured Inconel 718 and e_ects of post heat treatments. Mater. Sci. Eng. A 2017, 693, 151-163.

19. Paula Rojas, Rosa Vera, Carola Martinez, Maria Villaroel, 'Effect of the Powder Metallurgy manufacture Process on the Electrochemical Behaviour of Copper, Nickel and Copper Nickel Alloys in Hydrochloric Acid", Int. J. Electrochem. Sci., 11 (2016) 4701-4711 